\title{
PENGEMBANGAN INSTRUMEN KETERAMPILAN PROSES SAINS TEMA LINGKUNGAN SAHABAT KITA KD MENGANALISIS SIKLUS AIR DAN DAMPAKNYA PADA PERISTIWA DI BUMI SERTA KELANGSUNGAN MAKHLUK HIDUP DAN LOCUS OF CONTROL SISWA KELAS V SEKOLAH DASAR
}

\author{
N.W. Destriantini ${ }^{1}$, N. Dantes ${ }^{2}$, I.M. Gunamantha ${ }^{3}$ \\ ${ }^{123}$ Program Studi Pendidikan Dasar \\ Universitas Pendidikan Ganesha \\ Denpasar, Indonesia \\ e-mail: $\frac{\text { destriantini@undiksha.ac.id }{ }^{1}}{\underline{\text { made.gunamantha@ }}, \frac{\text { nyoman.dantes@undiksha.ac.id }{ }^{3}}{\text { undiks.id }} \text {, }}$
}

\begin{abstract}
Abstrak
Penelitian ini bertujuan untuk mengetahui dan mendeskripsikan: 1) validitas instrumen keterampilan proses sains dan locus of control; 2) reliabilitas instrumen keterampilan proses sains dan locus of control. Jenis penelitian ini merupakan penelitian pengembangan Research and Development (R\&D). Model pengembangan yang digunakan adalah model 4D (four $D$ ) yang terdiri atas empat tahapan, yaitu: define (pendefinisian), design (perancangan), develop (pengembangan), dan disseminate (penyebaran). Data yang dikumpulkan pada penelitian ini meliputi data keterampilan proses sains dan locus of control. Data keterampilan proses sains dikumpulkan berupa lembar pertanyaan (soal uraian), sedangkan data locus of control dikumpulkan dengan menggunakan lembar pernyataan (kuesioner). Data dianalisis menggunakan CVR dan Alpha Cronbach. Validitas diukur menggunakan uji expert sebanyak 5 orang yang terdiri dari 2 orang dosen ahli dan 3 orang guru. Hasil penelitian menunjukkan bahwa: 1) Untuk instrumen keterampilan proses sains, berdasarkan uji ahli terdapat 22 soal yang dinyatakan valid dengan $0,60 \leq v_{y} \geq 1,00$ dan 3 soal dinyatakan tidak valid dari 25 soal yang diuji. Hasil uji reliabilitas sebesar 0,71 berada pada kategori tinggi; 2 ) Untuk instrumen locus of control, berdasarkan uji ahli terdapat 43 soal yang valid dengan $0,60 \leq v_{y} \geq 1,00$ dan 7 soal dinyatakan tidak valid dari 50 soal yang diuji. Hasil uji reliabilitas sebesar 0,70 berada pada kategori tinggi. Berdasarkan hasil tersebut, disimpulkan bahwa penelitian ini menghasilkan instrumen keterampilan proses sains dan locus of control yang valid dan reliabel.
\end{abstract}

Kata Kunci : Keterampilan Proses Sains; Locus Of Control; Pengembangan Instrumen

\begin{abstract}
This research aimed to determine and described: 1) the validity of the science process skills instrument and the locus of control; 2) instrument reliability of science process skills and locus of control. This type of research was a development research of Research and Development (R\&D) research. The development model used in this research was the 4D (four D) model which consisted of four stages, namely: define, design, develop, and disseminate. Data collected in this research included data on science process skills and locus of control. Science process skills data were collected in the form of question sheets (essay questions), while the locus of control data were collected by using statement sheets (questionnaires). Data were analyzed by using CVR and Alpha Cronbach. Validity was measured by using an expert test of 5 people consisting of 2 expert lecturers and 3 teachers. The results of this research showed that: 1) For the science process skill instruments, based on the expert tests, there were 22 questions which were declared valid with $0,60 \leq v y \geq 1,00$ and 3 questions were declared invalid of 25 questions tested. The reliability test results of 0,71 was in the high category; 2) For the locus of control instrument, based on the expert tests, there were 43 valid questions with 0,60 y vy $\geq 1,00$ and 7 questions were invalid of the 50 questions tested. The reliability test results of 0,70 were in the high category. Based on these results, it was concluded that this research produced valid and reliable science process skills and locus of control instruments.
\end{abstract}


Keywords : Science Process Skill; Locus Of Control; Instrument Of The Development

\section{PENDAHULUAN}

Kegiatan pembelajaran di sekolah
tidak hanya menghafal melainkan
menekankan pada pengembangan keterampilan siswa. Bahkan, keterampilan sangat diperlukan dalam mempelajari segala bidang keilmuan. Salah satunya adalah ilmu pengetahuan alam (IPA). Materi mengenai segala hal yang berkaitan dengan alam dan isinya dipelajari dalam IPA. Pembelajaran IPA bertujuan untuk mengembangkan konsep yang berkaitan dengan kehidupan seharihari. Selain itu, ciri utama pembelajaran adalah adanya interaksi serta memiliki komponen - komponen yang berhubungan untuk mencapai tujuan pembelajaran (Dewi, 2017). Sama halnya dengan Samatowa (2011), menyatakan bahwa proses pembelajaran IPA menekankan pada pemberian pengalaman langsung untuk mengembangkan kompetensi agar menjelajahi dan memahami alam sekitar secara ilmiah. Pembelajaran IPA akan lebih bermakna jika siswa mampu memahami proses pembelajaran yang sekaligus sebagai hakikat pembelajaran IPA itu sendiri (Maulidati, 2018).

Pemerolehan pengetahuan IPA dapat difasilitasi melalui peningkatan keterampilan proses sains. Keterampilan proses sains adalah semua keterampilan yang diperlukan untuk memperoleh, mengembangkan, dan menerapkan konsep-konsep, hukum-hukum, dan teoriteori IPA, baik berupa keterampilan mental, keterampilan fisik (manual) maupun keterampilan sosial (Rustaman, 2005). TIMSS 2015 menunjukkan kemampuan siswa kelas IV SD di Indonesia belum memuaskan yaitu berada di peringkat 44 dari 49 negara (Nizam, 2016). Sementara itu, PISA 2018 juga memberikan hasil skor dan pemeringkatan negara-negara OECD dalam kemampuan sains. Indonesia menduduki peringkat 70 dari 78 negara anggota. Ada beberapa hal yang berpotensi memengaruhi skor IPA siswa, diantaranya perubahan kurikulum dan penggunaan IT dalam proses pembelajaran. Pembelajaran IPA dikatakan berhasil apabila semua tujuan pembelajaran yang telah ditentukan dapat tercapai, yang terungkap dalam hasil belajar IPA. IPA merupakan mata pelajaran yang mempelajari peristiwa peristiwa yang terjadi di alam. Pelajaran IPA di SD memuat materi tentang pengetahuan alam yang dekat dengan kehidupan siswa SD. Siswa diharapkan dapat mengenal dan mengetahui pengetahuan-pengetahuan alam tersebut dalam kehidupan sehari - harinya (Purbarani, 2018). Mata Pelajaran IPA adalah salah satu mata pelajaran wajib yang masuk dalam struktur kurikulum 2013 karena berguna dalam pemecahan masalah (Agustini, 2019).

Pembelajaran IPA erat kaitannya dengan keterampilan proses sains. Menurut Suastra (2017), menyatakan keterampilan proses sains memiliki delapan aspek yang perlu dikuasai siswa, diantaranya keterampilan mengamati, menafsirkan, meramalkan, menggunakan alat dan bahan, menerapkan konsep, merencanakan kegiatan, berkomunikasi, dan bertanya. Kurikulum 2013 mengutamakan pembelajaran dengan mengembangkan hard skill dan soft skill serta siswa mampu menguasai kompetensi dalam ranah kognitif, afektif, dan psikomotorik. Permendikbud No. 23 Tahun 2016 tentang Standar Penilaian Pendidikan yang merupakan kriteria mengenai lingkup, tujuan, manfaat, prinsip, mekanisme, prosedur, dan instrumen penilaian hasil belajar siswa yang digunakan sebagai dasar dalam penilaian hasil belajar siswa pada pendidikan dasar dan pendidikan menengah. Penilaian pendidikan merupakan proses pengukuran hasil belajar siswa melalui pengumpulan dan pengolahan informasi mengenai pengetahuan, keterampilan dan sikap. Oleh sebab itu, kedua hal tersebut harus dikembangkan oleh guru dalam merancang pembelajaran. Selain itu, 
penilaian pembelajaran juga menekankan kemampuan berpikir untuk mengembangkan kompetensi hard skill serta soft skill siswa yang sesuai dengan kurikulum 2013.

Pengimplementasian keterampilan proses sains di kelas tidak hanya kemampuan kognitif yang dilatih melainkan sikap seperti tanggung jawab, disiplin, usaha, dan kemampuan siswa. Kemampuan atau sikap seperti ini perlu menjadi perhatian guru dalam pembelajaran di kelas. Sikap-sikap tersebut dikenal dengan locus of control. Salah satu karakteristik siswa yang berpengaruh dalam pembelajaran sains adalah locus of control. Locus of control adalah sikap kendali seseorang terhadap dirinya yang mengacu kepada tanggung jawab terhadap suatu pekerjaan yang berasal dari dalam atau luar diri. Dimensi dari locus of control yaitu locus of control internal dan locus of control eksternal (Septiani, 2016). Sehubungan dengan hal tersebut, locus of control penting dalam konteks pencapaian karena dihipotesiskan untuk mempengaruhi suatu perilaku. Siswa yang percaya bahwa mereka memiliki kendali atas keberhasilan dan kegagalan, mereka akan berusaha dalam menyelesaikan tugas yang diberikan sebagai bentuk tanggungjawab. Sehingga pada gilirannya, upaya dan ketekunan akan mencapai keberhasilan (Phares, 1976).

Siswa yang memiliki locus of control internal lebih perseptif dan lebih siap untuk belajar tentang lingkungannya. Siswa mengajukan lebih banyak pertanyaan dan memproses informasi lebih efisien daripada locus of control eksternal. Siswa memiliki kecenderungan penguasaan yang lebih besar, kemampuan pemecahan masalah yang lebih baik, dan lebih banyak kesamaan prestasi. Siswa belajar lebih cepat bagaimana bekerja sama (Barbara, 2009). Sebaliknya siswa yang memiliki locus of control eksternal lebih yakin bahwa keberhasilan karena sebuah kebetulan dan diberikan oleh lingkungannya. Mereka cenderung lebih suka menunggu suatu keberhasilan tanpa melakukan suatu usaha sehingga tidak pernah ingin melatih diri menyelesaikan tugas yang diberikan oleh guru. Weiner (1974) mengajukan empat unsur yang dapat menentukan keberhasilan dan kegagalan seseorang dalam mengendalikan dirinya. Empat unsur tersebut yaitu (1) kemampuan, (2) usaha, (3) kesulitan tugas, dan (4) nasib. Weiner mengatakan bahwa faktor kemampuan dan usaha adalah tergolong sebagai penyebab internal (locus of control internal) dari siswa, sedangkan faktor kesulitan tugas dan nasib tergolong sebagai penyebab eksternal (locus of control eksternal) siswa.

Keterampilan proses sains perlu dilatihkan sejak dini kepada siswa dalam proses pembelajaran, begitu juga mengenai locus of control siswa yang harus diketahui oleh guru. Oleh sebab itu, guru dapat mengukur kemampuan siswa melalui sebuah instrumen. Terdapat dua jenis instrumen yaitu instrumen tes yang dapat digunakan untuk mengukur keterampilan proses sains dan instrumen nontes yang digunakan untuk mengukur locus of control siswa. Berdasarkan hasil observasi yang dilakukan di salah satu SD Negeri yang ada di Kecamatan Denpasar Timur, ditemukan bahwa pada pembelajaran IPA guru sudah melaksanakan proses pembelajaran yang menekankan pada keterampilan proses sains. Namun hal tersebut tidak dibarengi oleh penggunaan instrumen yang baik. Pada kenyataannya dalam mengukur keterampilan proses sains siswa, guru hanya menggunakan soal-soal yang terdapat di buku penunjang saja. Kualitas dari instrumen tersebut tidak sesuai dengan ranah kognitif siswa kelas $\mathrm{V}$ karena soal berada di bawah C4. Padahal untuk siswa kelas tinggi, ranah kognitif yang digunakan berada di C4 ke atas. Ini menunjukkan bahwa instrumen penilaian yang digunakan terbatas pada LOTS.

Hal utama yang ingin dikembangkan dalam pembelajaran IPA bukan saja memahami konsep namun siswa memiliki pengalaman yang bermakna. Bagaimanapun pemahaman konsep sains tidak hanya hasil (produk) saja, tetapi proses untuk mendapatkan konsep tersebut sangat penting dalam 
membangun pengetahuan siswa. Salah satu konsep materi IPA yang dibelajarkan di SD yaitu mengenai siklus air. Siklus air sudah sering dialami oleh siswa setiap hari, namun setiap siswa memiliki potensi yang berbeda mengenai pemahaman materi sehingga tidak semua memahami materi tersebut. Sejalan pernyataan tersebut, hasil observasi juga menunjukkan bahwa di sekolah tersebut guru belum pernah membuat instrumen mengenai locus of control. Hal tersebut dibuktikan dari belum pernahnya guru dalam penggunaan kuesioner untuk menentukan locus of control siswa. Sehingga guru tidak mengetahui secara pasti kendali siswa terhadap dirinya sendiri. Padahal hal ini merupakan salah satu faktor dalam meningkatkan kemampuan siswa di sekolah karena berkaitan dengan cara pandang siswa mengenai peristiwa yang terjadi sebagai konsekuensi perbuatannya. Oleh sebab itu, guru dapat mengetahui seberapa jauh perbuatan yang akan dilakukan siswa dengan akibat atau hasil yang didapatkan nanti (Suryabrata, 2012).

Berkaitan dengan pernyataan tersebut, melalui pengembangan instrumen yang dilakukan oleh guru dapat melengkapi perkembangan siswa baik dari kogntif maupun keterampilannya. Penggunaan asesmen dapat membantu guru untuk mengetahui perkembangan siswa dari segi kognitif maupun sikapnya sehari - hari serta mampu mengimplementasikan pembelajaran yang sesuai dengan kurikulum 2013 (Ayu, 2018). Begitu halnya siswa juga harus mampu memiliki kemampuan dalam menghadapi tantangan hidup di era revolusi industri 4.0. Pendidikan di era ini menuntut sumber daya manusia yang memiliki critical thinking, creativity, communication, and collaboration atau dikenal dengan 4C. Selain itu, terjadi perubahan cara belajar, cara berpikir dan bertindak para siswa dalam mengembangkan pengetahuannya di segala bidang (Septiasari, 2020). Pada era ini juga siswa dan guru dapat melaksanakan proses pembelajaran di mana saja dan kapan saja. Guru dalam menghadapi tantangan ini dituntut untuk siap berubah dan beradaptasi dengan teknologi yang ada. Pembangunan mutu sumber daya manusia Indonesia bertumpu pada guru, sehingga guru diharapkan mampu meningkatkan profesionalitas menuju pendidikan abad 21. P21 (Partnership for 21st Century Learning) mengembangkan framework pembelajaran di abad 21 yang menuntut siswa untuk memiliki kecakapan hidup. National Education Association telah mengidentifikasi keterampilan abad ke-21 sebagai keterampilan "The 4Cs" (Dwimayanti, 2020). Guru pada zaman ini harus mampu memposisikan diri agar menjadi guru yang mampu menghasilkan sumber daya yang berkualitas.

Zaman modern seperti sekarang ini, baik pendidik maupun siswa dihadapkan pada tantangan era globalisasi. Era ini ditandai dengan keterampilanketerampilan masyarakat yang semakin berkembang. Selain keterampilan dasar (membaca, menulis dan berhitung) masyarakat juga dituntut memiliki kemampuan belajar sepanjang hayat, mengelola informasi, mengelola sumber daya, mengelola hubungan sosial, mengelola diri, memecahkan masalah, mengambil keputusan, berpikir kreatif, dan lain sebagainya. Untuk itu, hal tersebut harus disiapkan, salah satunya dengan pendidikan. Pembelajaran kurikulum 2013 berorientasi kepada usaha-usaha penyiapan lahirnya generasi emas Indonesia 2045 yang didambakan, yaitu generasi yang memiliki kompetensi yaitu sikap, pengetahuan dan keterampilan yang harus dimiliki, dihayati, dan dikuasai oleh siswa setelah mempelajari suatu muatan pembelajaran, menamatkan suatu program, atau menyelesaikan satuan pendidikan tertentu (Purbarani, 2018).

Kurikulum 2013 merupakan kurikulum yang sedang diterapkan diberbagai sekolah dasar. Kurikulum dengan proses melaksanakan penyederhanaan dan tematik-integratif, menambah jam pelajaran dan bertujuan untuk mendorong siswa, mampu lebih baik dalam materi pembelajaran dan diharapkan siswa kita memiliki kompetensi sikap, keterampilan, dan pengetahuan jauh lebih baik. Mereka lebih kreatif, 
inovatif, dan lebih produktif, sehingga nantinya mereka bisa sukses dalam menghadapi berbagai persoalan dan tantangan di zamannya, memasuki masa depan yang lebih baik (Nilayanti, 2019).

Berdasarkan uraian tersebut, maka tujuan penelitian ini adalah untuk mengetahui validitas isi instrumen keterampilan proses sains dan validitas isi locus of control. Tujuan lainnya yaitu untuk mengetahui reliabilitas menurut expert instrumen keterampilan proses sains dan mengetahui reliabilitas menurut expert instrumen locus of control.

\section{METODE}

Rancangan penelitian ini adalah jenis penelitian pengembangan atau Research and Development (R\&D). Metode penelitian ini digunakan untuk menghasilkan suatu produk serta menguji keefektifan produk tersebut (Sugiyono, 2015). Produk yang dikembangkan melalui penelitian pengembangan ini adalah instrumen keterampilan proses sains dan locus of control. Subjek dalam penelitian ini terdapat expert yang terlibat yaitu dua orang dosen ahli dan tiga orang praktisi yang memvalidasi serta memberikan saran terhadap pengembangan instrumen keterampilan proses sains dan locus of control. Sedangkan variabel yang digunakan dalam penelitian ini adalah keterampilan proses sains dan locus of control.

Penelitian ini menggunakan model pengembangan 4D (four $D$ ). Menurut Thiagarajan (1974) menyatakan bahwa model ini terdiri atas empat tahapan, yaitu: (1) define (pendefinisian), (2) design (perancangan), (3) develop (pengembangan), dan (4) disseminate (penyebaran). Tahapan yang pertama yaitu define, adapun kegiatannya adalah melakukan analisis kebutuhan, menentukan tema, KD, dan indikator. Pada tahap design dilakukan kegiatan berupa pemilihan pola instrumen yang digunakan, membuat kisi - kisi instrumen keterampilan proses sains dan locus of control. Kemudian, mengimplementasikan kisi-kisi menjadi butir-butir instrumen. Pada tahap yang ketiga yaitu develop, dilakukan pengujian instrumen oleh expert. Data mengenai validitas dan reliabilitas instrumen dikumpulkan berdasarkan pendapat masing - masing expert. Tahap yang terakhir yaitu disseminate tidak dapat dilaksanakan karena pemerintah menetapkan physical distancing. Oleh sebab itu, seluruh aktivitas dilaksanakan di rumah masing masing (Work From Home).

Metode pengumpulan data pada instrumen keterampilan proses sains menggunakan tes dalam bentuk uraian dilengkapi dengan rubrik penskoran. Instrumen locus of control berupa kuesioner. Pada tiap butir pernyataan disediakan lima alternatif jawaban yang diklasifikasikan sesuai dengan skala sikap pola likert, yaitu sangat setuju, setuju, kurang setuju, tidak setuju, dan sangat tidak setuju. Untuk statemen positif pilihan sangat setuju skornya 5 , setuju skornya 4 , kurang setuju skornya 3 , tidak setuju skornya 2, sangat tidak setuju skornya 1 . Untuk statemen yang negatif sangat setuju skornya 1 , setuju skornya 2 , kurang setuju skornya 3 , tidak setuju skornya 4 , dan sangat tidak setuju skornya 5 . Kisi-kisi pada variabel locus of control menggunakan dua dimensi yaitu locus of control internal dan locus of control eksternal. Indikator yang digunakan yaitu berjumlah empat yaitu kemampuan dan usaha yang termasuk ke dalam locus of control internal. Sedangkan, kesulitan tugas dan nasib tergolong ke dalam locus of control eksternal. Jumlah pernyataan yang digunakan yaitu sebanyak 50 .

Analisis data validitas menggunakan rumus CVR. Kriteria valid tidaknya isi butir rubrik menggunakan acuan nilai minimum CVR berdasarkan jumlah panelis. Isi butir dinyatakan valid apabila memiliki nilai CVR $\geq 0,60$. Sedangkan, reliabilitas untuk kedua instrumen ditentukan dengan rumus Alpha Cronbach. Soal dan pernyataan dikatakan reliabel yang berada pada interval $0,60<r_{11} \leq 0,80$.

\section{HASIL DAN PEMBAHASAN}

Instrumen keterampilan proses sains dan locus of control dikembangkan menggunakan model 4D (four $D$ ). Menurut Thiagarajan, 1974 menyatakan bahwa model ini terdiri atas empat tahapan, yaitu: 
(1) define (pendefinisian), (perancangan), (3)

(2) design develop (pengembangan), dan (4) disseminate (penyebaran).

Pada tahap define, terdapat tiga kegiatan yaitu melakukan analisis kebutuhan, melakukan analisis teoritik dengan menentukan grand teori dari masing - masing variabel untuk menentukan tema, KD, dan indikator sesuai instrumen yang akan dibuat. Kegiatan terakhir pada tahap define yaitu menyusun kisi-kisi melalui analisis tema, $\mathrm{KD}$, dan indikator yang sudah dilaksanakan sebelumnya.

Pada tahap design dilakukan kegiatan berupa pemilihan pola instrumen yang digunakan, yaitu jenis soal uraian untuk instrumen keterampilan proses sains sedangkan pada instrumen locus of control menggunakan jenis soal nontes yang pengembangannya berupa kuesioner. Setelah pemilihan pola instrumen kemudian dilanjutkan dengan membuat kisi-kisi instrumen keterampilan proses sains dan locus of control. Kemudian, mengimplementasikan kisi-kisi menjadi butir-butir instrumen. Instrumen keterampilan proses sains dikembangkan berupa soal uraian dengan jumlah 25 butir soal, sedangkan sebanyak 50 pernyataan untuk kuesioner pada instrumen locus of control.

Pada tahap yang ketiga yaitu develop, dilakukan pengujian instrumen oleh expert yaitu dua orang dosen ahli dan tiga orang praktisi yaitu guru kelas V SD. Adapun expert yang dilibatkan dalam penelitian ini sebagai validator instrumen yaitu 2 orang dosen dari jurusan pendidikan dasar yaitu Prof. Dr. Nyoman Dantes dan Dr. I Made Gunamantha, ST., MM. Selain itu, divalidasi juga oleh 3 orang praktisi di bidang pendidikan yang berprofesi sebagai guru sekolah dasar yaitu Erry Trisna Nurhayana, S.Pd., M.Pd., Desak Ketut Ayu Juniantari, S.Pd., M.Pd., dan Kadek Putri Pebiani, S.Pd., M.Pd. Data mengenai validitas dan reliabilitas instrumen dikumpulkan berdasarkan pendapat masing - masing expert. Dalam menyusun instrumen yang memiliki validitas isi, maka pengujiannya dapat dilakukan dengan membandingkan antara isi instrumen dengan kisi-kisi instrumen yang telah dibuat sebelumnya. Sehingga pengujian validitas dapat dilakukan dengan mudah dan sistematis (Sugiyono, 2010). Soal dapat dikatakan valid apabila dengan tepat mengukur apa yang hendak diukur oleh peneliti.

Berdasarkan hasil validasi instrumen keterampilan proses sains yang dilakukan oleh expert terdapat 25 butir soal yaitu sebanyak 22 soal yang valid dengan 0,60 $<v_{y} \leq 1,00$ dan 3 soal yang tidak valid. Hasil hitung reliabilitas instrumen keterampilan proses sains sebesar 0,71 yang berada pada rentang $0,60<r_{11} \leq$ 0,80 atau berada pada kategori derajat reliabilitas tinggi (baik). Nomor soal yang valid yaitu 1, 2, 3, 4, 5, 6, 7, 8, 9, 10, 12, 13, 16, 17, 18, 19, 20, 21, 22, 23, 24 dan 25. Sedangkan nomor soal yang tidak valid yaitu 11, 14, dan 15 .

Butir soal nomor 11 merupakan salah satu butir soal yang tidak valid, adapun bunyi soalnya yaitu "Pencemaran air adalah suatu perubahan keadaan di suatu tempat penampungan air seperti lautan akibat aktivitas manusia. Selain itu, laut merupakan bagian penting dalam siklus air. Jika pencemaran air tidak dapat dikendalikan, apakah yang akan terjadi? Jelaskanlah!". Selain itu, butir soal juga dilengkapi dengan gambar suatu pantai yang sudah tercemar serta terlihat banyak sampah yang ada di sana. Kemudian dilakukan perhitungan validasi sehingga mendapatkan nilai CVR sebesar 0,2 yang berada pada kategori tidak valid. Sesuai dengan validasi yang dilakukan expert, ketidakvalidan ditunjukkan karena kalimat pada butir soal nomor 11 dianggap tidak sesuai dengan indikator. Pada indikator menjelaskan faktor-faktor yang memengaruhi siklus air yang terjadi dalam tanah, sedangkan soal mengenai pencemaran air laut. Sehingga disarankan untuk mengubah butir soal tersebut.

Butir soal pada nomor 14 memiliki perhitungan nilai CVR sebesar 0,2. Nilai tersebut menunjukkan butir soal tergolong pada kategori tidak valid. Adapun bunyi soal pada butir soal nomor 14 yaitu, "Berdasarkan gambar di atas, tulislah alat dan bahan yang digunakan dalam percobaan siklus air tersebut!". Selain itu, 
soal juga dilengkapi dengan gambar percobaan siklus air. Sesuai dengan validasi yang dilakukan expert, ketidakvalidan ditunjukkan karena kalimat pernyataan dianggap tidak sesuai dengan indikator. Pada indikator tertulis yaitu terampil menggunakan alat dan bahan dalam percobaan siklus air, dengan kata lain bahwa indikator mengukur kompetensi keterampilan. Sedangkan pada butir soal tidak menunjukkan bagaimana cara menggunakan alat dan bahan sesuai dengan gambar. Sehingga disarankan untuk mengubah butir soal tersebut agar sesuai dengan kompetensi yang diharapkan pada indikator. Butir soal terakhir yang tidak valid yaitu nomor soal 15, dikarenakan tidak sesuai dengan indikator soal. Pada indikator mengaharapkan adanya suatu kemampuan untuk menggunakan alat dan bahan dalam suatu percobaan siklus air. Namun pertanyaan pada butir soal mengarah kepada penulisan alat dan bahan yang digunakan pada percobaan siklus air. Oleh sebab itu, berdasarkan nilai perhitungan CVR maka didapatkan nilai sebesar 0,2 yang tergolong kedalam soal yang tidak valid, sehingga disarankan untuk merevisi butir soal nomor 15 agar sesuai dengan ketercapaian indikator soal.

Hasil perhitungan validitas instrumen locus of control terdapat sebanyak 43 butir pernyataan yang valid dengan $0,60<v_{y} \leq$ 1,00 dan 7 butir pernyataan yang tidak valid. Nilai reliabilitas yang dihasilkan yaitu sebesar 0,70 yang berada pada rentang $0,60<r_{11} \leq 0,80$ atau berada pada kategori derajat reliabilitas tinggi (baik). Butir pernyataan yang valid yaitu pernyataan nomor $1,2,3,4,5,8,9,10$, $11,12,13,14,15,16,17,18,19,20,22$, $23,24,25,26,27,28,29,30,32,33,34$, 36, 37, 39, 40, 41, 42, 43, 44, 45, 46, 48, 49 , dan 50 . Sedangkan nomor pernyataan yang tidak valid yaitu $6,7,21,31,35,38$, dan 47. Pernyataan yang tidak valid diputuskan untuk diperbaiki dari segi redaksinya. Salah satu butir pernyataan yang tidak valid yaitu pernyataan nomor 6 yang berbunyi "Saya berkemampuan memimpin kelompok diskusi materi IPA". Sesuai dengan validasi yang dilakukan expert, ketidakvalidan ditunjukkan karena kalimat pernyataan dianggap tidak sesuai dengan indikator. Dimensi pada pernyataan ini adalah kemampuan, namun pada pernyataan nomor 6 belum mencerminkan dimensi kemampuan tersebut. Berdasarkan penilaian didapatkan nilai CVR sebesar 0,2 sehingga pernyataan nomor 6 tergolong tidak valid, sehingga disarankan untuk mengubah pernyataan dengan kondisi yang lain.

Butir pernyataan nomor 7 yang berbunyi "Kemampuan yang saya miliki kurang sehingga tidak mampu menyelesaikan tugas tepat waktu". Pernyataan ini termasuk similar paradoks antara pernyataan yang positif dan negatif, sehingga stemnya perlu diubah atau menggunakan kondisi yang lain. Hal ini untuk menghindari agar responden tidak langsung mengetahui pernyataan tersebut negatif. Berdasarkan hasil perhitungan validitas, didapatkan nilai CVR sebesar 0,2 sehingga pernyataan nomor 7 berada pada kategori tidak valid. Sesuai dengan validasi yang dilakukan judges, ketidakvalidan ditunjukkan karena susunan kalimat pada pernyataan tersebut kurang baik. Sehingga disarankan untuk mengubah kalimat pernyataan nomor 7 .

Butir pernyataan ketiga yang tidak valid yaitu pada nomor 21 yang berbunyi "Saya dapat menyelesaikan kesulitan tugas IPA dengan kelompok". Adapun nilai CVR dari pernyataan nomor 21 sebesar 0,2 dan berada pada kategori tidak valid. Sesuai dengan validasi yang dilakukan expert, ketidakvalidan ditunjukkan karena diksi yang digunakan tidak tepat sehingga menimbulkan makna ambigu terhadap pernyataan tersebut. Sehingga disarankan untuk mengubah kalimat pernyataan 21 dengan menggunakan diksi yang tepat.

Pernyataan yang tidak valid lainnya ditunjukkan oleh nomor 31 yang berbunyi "Saya tidak akan menunggu nasib baik untuk bisa menjadi juara kelas". Pernyataan tersebut memiliki nilai CVR 0,2 yang berada pada kategori tidak valid. Ketidakvalidan ditunjukkan karena pernyataan tersebut tidak dinyatakan secara jelas dan kurang mengkhusus. Sehingga disarankan untuk mengubah 
pernyataan nomor 31 agar mudah dipahami oleh responden.

Pernyataan tidak valid yang kelima yaitu nomor 35 yang berbunyi, "Saya berpikir bahwa semakin kaya maka menjadi semakin pintar", berdasarkan perhitungan didapatkan nilai CVR sebesar 0,2 dengan kategori tidak valid. Hal tersebut dikarenakan pada pernyataan nomor 35 menggunakan diksi yang tidak tepat sehingga pernyataan tersebut terkesan ambigu. Oleh sebab itu, disarankan untuk mengubah kalimat pada pernyataan nomor 35 dengan diksi yang tepat

Butir pernyataan yang tidak valid lainnya yaitu nomor 38, berbunyi "Perbedaan utama antara teman yang memiliki nilai tinggi dengan yang memiliki nilai rendah karena adanya faktor nasib". Pernyataan tersebut memiliki nilai CVR 0,2 yang berkategori tidak valid. Ketidakvalidan tersebut ditunjukkan karena pernyataan tidak sesuai dengan dimensi dari locus of control. Dimensi pada pernyataan ini adalah nasib, namun pada pernyataan soal nomor 38 tidak mencerminkan dimensi yang dimaksud. Sehingga disarankan untuk mengubah pernyataan nomor 38 yang sesuai dengan dimensi nasib.

Butir pernyataan yang tidak valid terakhir yaitu pernyataan nomor 47 yang berbunyi, "Saya enggan berkomunikasi selain teman dekat saya". Berdasarkan perhitungan didapatkan nilai CVR sebesar 0,2 yang memiliki kategori tidak valid. Hal tersebut ditunjukkan oleh tidak sesuainya pernyataan nomor 47 dengan dimensi dari locus of control. Adapun dimensi pada pernyataan tersebut adalah usaha, namun pada pernyataan belum mencerminkan dimensi yang dimaksud. Oleh sebab itu, pernyataan nomor 47 disarankan untuk diperbaiki agar sesuai dengan dimensi yang ada.

Berdasarkan hasil perhitungan validitas dan reliabilitas yang telah dijabarkan tersebut, maka penelitian ini sejalan dengan penelitian yang dilakukan oleh Nurhayati, dkk (2019). Instrumen keterampilan proses yang dikembangkan berbentuk pilihan ganda dan essay. Analisis uji validitas diperoleh rata - rata persentase skor dari tiga ahli yaitu sebesar 85, 56 yang berada pada kategori sangat baik sehingga instrumen yang dibuat dianggap layak. Berdasarkan uji validitas empirik yang dilakukan terdapat sebanyak 7 soal yang dinyatakan tidak valid sehingga soal tersebut dibuang dan tidak digunakan. Sedangkan untuk tingkat reliabilitas soal sangat kuat untuk soal pilihan ganda dan tingkat reliabilitas sedang untuk soal berbentuk essay.

Penelitian lain yang sejalan dengan penelitian ini juga dikembangkan oleh Marlena (2019) yang berdasarkan rekapitulasi keterampilan proses sains siswa diperoleh hasil bahwa nilai siswa yaitu 30 (kriteria rendah), nilai 55 (kriteria sedang), dan nilai 95 (kriteria tinggi). Data tersebut diambil dari responden yang berjumlah 16 orang dengan menyebarkan instrumen dalam bentuk angket berstruktur. Hal ini menandakan bahwa sebagian siswa belum memiliki keterampilan proses sains dan sebagiannya sudah memiliki keterampilan proses sains. Penelitian terakhir yang sejalan dengan penelitian ini yaitu penelitian yang dilakukan oleh Hendryadi (2017). Hasil yang ditunjukkan pada studi 1 memperlihatkan nilai item - item yang digunakan memiliki konsistensi internal yang baik $(>0.70)$, yaitu 0,819 untuk komponen internal dan 0,717 untuk komponen eksternal. Sedangkan untuk reliabilitas menggunakan pendekatan paralel yang menghasilkan nilai sig sebesar $0,000 \quad(<0,05)$ sehingga terbukti kedua komponen memiliki skor yang berbeda secara signifikan. Hasil yang ditunjukkan pada studi 2 disimpulkan bahwa 8 item yang digunakan dalam pengukuran locus of control sudah menunjukkan kecocokan untuk model pengukuran yang baik.

Menurut Kemendikbud (2013), pembelajaran pada kurikulum 2013 didasarkan pada pendekatan ilmiah (scientific approach), dimana siswa memiliki kemampuan dalam mengamati, menanya, mengumpulkan informasi, mengasosiasi atau menalar dan mengkomunikasikan. Berdasarkan hal tersebut, pembelajaran IPA, khususnya di SD mampu mengarahkan siswa untuk 
membelajarkan siswa dalam melakukan penyelidikan, mengumpulkan data, membuat hipotesis, serta menganalisis untuk memecahkan suatu permasalahan. Oleh sebab itu, instrumen keterampilan proses sains sangat penting bagi siswa karena mampu melatihkan keterampilan proses sains agar mampu meningkatkan kerberhasilan belajar siswa secara optimal.

Instrumen locus of control sangat penting bagi siswa karena mampu memahami kontrol terhadap dirinya sendiri baik dari dalam ataupun luar diri sehingga mampu mengembangkan kemampuannya. Selain itu, instrumen locus of control ini mampu untuk memberikan semangat kepada siswa bahwa kesuksesan dapat diperoleh melalui kerja keras. Sedangkan untuk siswa yang sudah memiliki kepercayaan diri maka akan sangat membantunya untuk cepat meraih kesuksesan.

Tahap yang terakhir yaitu disseminate tidak dapat dilaksanakan karena pemerintah menetapkan physical distancing. Oleh sebab itu, seluruh aktivitas dilaksanakan di rumah masing masing (Work From Home). Salah satu kebijakan yang dikeluarkan yaitu belajar dari rumah (BDR).

\section{PENUTUP}

Secara umum penelitian ini dapat disimpulkan bahwa tahapan pengembangan instrumen menggunakan model 4D meliputi tahap define (pendefinisian), design (perancangan), develop (pengembangan), dan disseminate (penyebaran). Untuk tahapan terahir yaitu disseminate (penyebaran), tidak dapat dilaksanakan oleh peneliti akibat dari adanya kebijakan physical distancing yang mengharuskan seluruh lapisan masyarakat termasuk siswa untuk belajar dari rumah (BDR).

Penelitian pengembangan ini menghasilkan instrumen keterampilan proses sains berupa soal uraian sebanyak 25 butir. Selanjutnya dilakukan analisis uji validitas isi untuk instrumen keterampilan proses sains pada siswa kelas V SD menggunakan CVR. Berdasarkan hasil perhitungan CVR didapatkan 22 butir instrumen yang valid dengan $0,60 \leq v_{y} \geq$ 1,00 dan 3 instrumen yang tidak valid. Selanjutnya perhitungan reliabilitas instrumen menurut expert instrumen keterampilan proses sains pada siswa kelas V SD yaitu sebesar $r_{11}=0,71$ (terkategori tinggi).

Instrumen kedua yaitu locus of control dengan mengembangkan kuesioner berjumlah 50 pernyataan. Berdasarkan hasil dari perhitungan CVR, didapatkan 43 pernyataan yang valid dengan $0,60 \leq v_{y} \geq 1,00$ dan 7 pernyataan yang tidak valid. Menurut expert, instrumen locus of control pada siswa kelas $\mathrm{V}$ SD sebesar $r_{11}=0,70$ (terkategori tinggi).

Berdasarkan simpulan yang telah dikemukakan, maka peneliti merekomendasikan hal-hal berikut yaitu penelitian ini diharapkan dapat meningkatkan proses pembelajaran yang bermakna bagi siswa pada keterampilan proses sains dan locus of control untuk mengembangkan dirinya dan meraih keberhasilan belajar yang optimal. Selain itu, penelitian ini diharapkan dapat dijadikan pedoman dalam merancang pengembangan instrumen keterampilan proses sains dan locus of control siswa dan diharapkan juga dapat menjadi informasi dan masukan bagi para peneliti bidang pendidikan untuk meneliti aspek atau variabel lain yang diduga memiliki kontribusi terhadap teori-teori pembelajaran serta dapat memberikan perubahan yang lebih baik sesuai dengan perkembangan teknologi dan informasi, maka secara otomatis tujuan pendidikan akan tercapai secara optimal.

\section{DAFTAR RUJUKAN}

Agustini. A. 2019. Pengaruh Model Pembelajaran Starter Experiment Approach terhadap Keterampilan Proses dan Hasil Belajar IPA Siswa Kelas VI SD. Jurnal Pendidikan Dasar Indonesia. Vol. 3. No. 2. Agustus 2019

Ayu, P.E. Sastrika. 2018. Pengembangan Instrumen Asesmen Keterampilan Belajar dan Berinovasi pada Mata Pelajaran IPA SD. Jurnal Pendidikan 
Dasar Indonesia, Vol.2, No. 2, Agustus 2018

Barbara. 2009. Fundamental Nursing Skill and Concept. United States of America.

Dewi, Komala. 2017. Pengaruh Strategi Guided Discovery Learning terhadap Hasil Belajar IPA ditinjau dari Kemampuan Berpikir Kritis Siswa Kelas IV Abiansemal Kabupaten Badung. Jurnal Pendidikan Dasar Indonesia, Vol.1, No. 1, Pebruari 2017

Dwimayanti, K. 2020. Pengembangan Rencana Pelaksanaan Pembelajaran (RPP) Tema Kegiatanku Kelas I Berbasis Kecakapan Belajar dan Berinovasi Abad 21. Jurnal Pendidikan Dasar Indonesia, Vol. 4, No. 1, Pebruari 2020.

Hendryadi. 2017. Pengembangan Skala Locus of Control. Jurnal Riset Manajemen dan Bisnis (JRMB) Fakultas Ekonomi UNIAT, 2(3), 417 -424 .

Kemendikbud. 2013. Permendikbud No. 81 A tentang Implementasi Kurikulum. Jakarta: Kementerian Pendidikan dan Kebudayaan

Marlena, Devi, dkk. 2019. Penyusunan Instrumen Tes Keterampilan Proses Sains pada Mata Pelajaran IPA di SMPN 14 Kota Bengkulu. Jurnal Penelitain Pendidikan Sains, Volume 9, No. 1, November 2019

Maulidati, . 2018. Pengaruh Pembelajaran Berpendekatan Saintifik Berorientasi Science Environment Technology Society terhadap Kemampuan Berpikir Kritis dan Hasil Belajar IPA Siswa Kelas V. Vol.2, No. 2, Agustus 2018

Nilayanti, P.M. 2019. Pengaruh Model Pembelajaran Talking Stick terhadap Kemampuan Berpikir Kreatif dan Literasi Sains Siswa Kelas IV SD.
Jurnal Pendidikan Dasar Indonesia. Vol. 3, No. 1, Pebruari 2019

Nizam. 2016. Ringkasan Hasil-hasil Asesmen Belajar Dari Hasil UN, PISA, TIMSS. INAP. Puspendik

Nurhayati, dkk. 2019. Pengembangan Instrumen Tes Keterampilan Proses Sains pada Materi Fisika untuk Siswa Sekolah Menengah Pertama. Jurnal Pendidikan, Vol. 17, No. 2, Desember 2019

Permendikbud. 2016. Nomor 23 Tahun 2016 Tentang Standar Penilaian Pendidikan. Tersedia di https://bsnpindonesia.org/wpcontent/ uploads/2009/09/Permendikbud Ta hun2016 Nomor023.pdf. (Diakses tanggal 14 Mei 2020).

Phares, E. J. 1976. Locus of control in personality. Morristown. NJ: General Learning Press.

Purbarani, Dyah Aini. 2018. Pengaruh Problem Based Learning Berbantuan Media Audio Visual terhadap Kemampuan Berpikir Kritis dan Hasil Belajar IPA di Sekolah Dasar. Vol. 2, No. 1, Pebruari 2018.

Rustaman, Nuryani Y. 2005. Strategi Belajar Mengajar Biologi. Malang: IKIP Malang.

Samatowa. 2011. Pembelajaran IPA di Sekolah Dasar. Jakarta: Indeks

Septiani, Yulia. 2016. Pengaruh Locus of Control terhadap Prestasi Belajar Matematika. JKPM, Vol.02, No. 01, 01 Des 2016

Septiasari. 2020. Pengaruh Model Reciprocal Teaching Berbasis Pendekatan Saintifik terhadap Kemampuan Berpikir Kritis dan Hasil Belajar IPA Kelas V. Jurnal Pendidikan Dasar Indonesia. Vol.4, No. 1, Pebruari 2020

Suastra. I W. 2017. Pembelajaran Sains Terkini. Singaraja: Universitas Pendidikan Ganesha 
Sugiyono. 2010. Metode Penelitian Pendidikan Pendekatan Kuantitatif, kualitatif, dan $R \& D$. Bandung: Alfabeta

.......... 2015. Metode Penelitian Pendidikan Pendekatan Kuantitatif, Kualitatif, dan $R \& D$. Bandung: Alfabeta.

Suryabrata, S. 2012. Psikologi Pendidikan. Jakarta: Raja Grafindo Persada.

Thiagarajan, S. et. Al. 1974. Instructional Development for Training Teacher of Exceptional Children. Bloomington Indiana: Indiana University
Weiner, B. 1974. Achievement Motivation and Attribution Theory. Morristown, $\mathrm{NJ}$ : General Learning Process. 